\title{
Kan Hamas være en brannmur mot palestinsk jihadisme?
}

Gjennom den væpnede motstandskampen har Hamas oppnådd økt respekt hos Palestinsk Islamsk Jihad og jihadistgrupper basert i palestinske flyktningleirer. Påvirkning fra Hamas har gjort gruppene mer villige til å inngå politiske kompromisser.

Dag Tuastad er førstelektor ved Institutt for kulturstudier og orientalske språk, UiO, og har i år utgitt boken Palestinske utfordringer.

I KJøLVANNET AV DEN ARABISKE VÅREN I 2011, før kuppet i Egypt, ble en mulig reorientering av politiske relasjoner mellom USA og islamistiske grupper diskutert i usA. Et argument $i$ diskusjonen var at Det muslimske brorskapet (DMB) kunne være en brannmur mot islamsk ekstremisme. Et moderat, bredt DMB kunne bidra til å inkorporere mye av den yngre befolkningsgruppens misnøye og avmakt, og dermed begrense radikalisering og rekruttering til globale jihadistgrupper. Mot denne brannmurmodellen ble det framholdt at konsolideringen av et islamistisk basert politisk system også kan ha en iboende radikaliseringseffekt, ved å være et slags samlebånd der politisk aktivitet defineres ut fra religiøs identitet. Alternative islamistiske modeller kan komme til å utfordre mer moderate, noe som kan gi økt politisk uro snarere enn en mer stabil politisk utvikling. ${ }^{1}$
Dette er en diskusjon som også er relevant for rollen til den palestinske islamske motstandsbevegelsen Hamas. Hamas er den eneste DMB-tilknyttede bevegelsen som i dag benytter vold som del av sin politiske kamp. Og til forskjell fra andre DMB-grupper står Hamas på Eus og USAs liste over terrororganisasjoner. ${ }^{2}$ Men samtidig er Hamas islamske nasjonalister, ikke globale jihadister. Hamas' kamp er geografisk begrenset til å være mot Israel, målet er å frigjøre Palestina, ikke å delta i en transnasjonal kamp på vegne av den muslimske ummaen der målet er å skape et islamsk kalifat på jorden og å drive ut de vantro. Og der Hamas har tilsluttet seg demokratiske verdier og prosesser, ser globale jihadistgrupper demokrati som en måte menneskets lovers settes over Guds lov. ${ }^{3}$ Og sist men ikke minst, mens AlQaida-affilierte grupper kjennetegnes av ideologisk rigiditet som gjør kompromisser med 


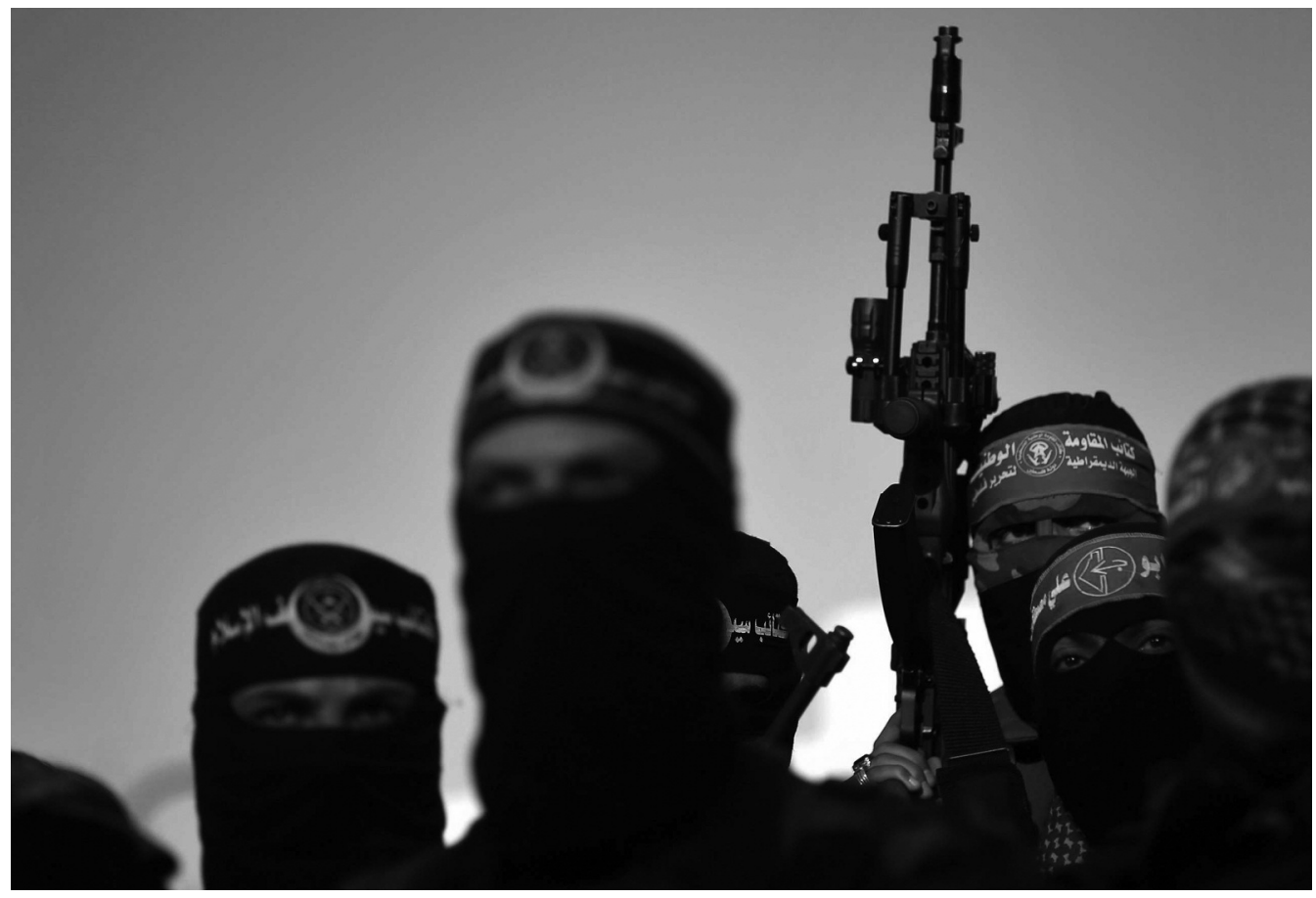

Hamas-krigere.

vantro til en teologisk umulighet, ${ }^{4}$ har Hamas signalisert en villighet til å inngå politiske kompromisser med Israel gjennom hudnaen, en langvarig våpenhvile. "La oss være ærlige. Vi kan ikke ødelegge Israel. Den praktiske løsningen for oss er å ha en stat. Da trenger vi ikke alle disse militsgruppene og vi har ikke lenger noe behov for å angripe», sa Hamas-lederen Ismail Abu-Shanab i 2003. ${ }^{5}$ Om Hamas' skisse til hudna, sa Abu-Shanab: "Vi er villige til å gi fred en sjanse, til å se om Israel er villig til å leve i fred. $n^{6}$

Forfattere som har skrevet i faglige publikasjoner om forholdet mellom Hamas og AlQaida er i all hovedsak enige om at det er en vesensforskjell mellom bevegelsene relatert til deres ulike politiske og ideologiske forankring, som beskrevet ovenfor.7 Al-Qaidas kritikk av Hamas har ikke bidratt til å radikalisere Hamas ideologisk. En mindre belyst problemstilling er: Hva med motsatt vei? Hvilken innflytelse har Hamas over Al-Qaida-affilierte palestinske jihadistgrupper? Og i forlengelsen av dette, hvilken innflytelse har Hamas på sin viktigste islamistiske konkurrent i palestinsk politikk, Palestinsk Islamsk Jihad (PIJ)? Dette, Hamas' innflytelse på PIj og om Hamas kan ses som en brannmur mot radikale jihadistgrupper på lignende måte som for DMB i Egypt, vil bli diskutert i denne artikkelen. En måte å undersøke temaet på er gjennom hvordan salafist-jihadistiske grupper i Libanon og PIj ser på Hamas' hudnatenkning. Gjør Hamas' vedvarende væpnede kamp mot Israel bevegelsen såpass respektert at også hudnaen kan godtas?

Før vi kommer dit skal vi imidlertid fokusere på det som også er et mål med denne artikkelen: å forstå Hamas' tenkning om hudna - deres alternative forslag til fredsprosess. Artikkelen begynner derfor med en beskrivelse av 


\section{DAG TUASTAD}

betingelsene Hamas stiller for en hudna, en gjennomgang av hudnaens historiske røtter, og statusen hudnaen har innad i Hamas.

\section{Hudnaen: Innhold og varighet}

I et brev til europeiske diplomater i 1999, som hadde forhørt seg med Hamas om hva deres tenkning om hudna gikk ut på, skriver Hamas at de er villige til å inngå en våpenhvile, det vil si avslutte alle fiendtlige handlinger mot Israel, i bytte mot:

1. Tilbaketrekking av israelske styrker fra Vestbredden og Gaza.

2. Evakuering av de israelske bosetningene på Vestbredden og Gaza.

3. Frigivelse av palestinske fanger.

4. Anerkjennelse av det palestinske folkets rett til selvbestemmelse. ${ }^{8}$

Hamas presiserte ikke varigheten av hudnaen i brevet. Men i 2004 uttalte Hassan Yousef, en Hamas-leder på Vestbredden, at en hudna kunne forlenges i det uendelige. ${ }^{9}$ I et intervju med forfatteren om hudnaen fortalte Osama Hamdan fra Hamas' politbyrå, at hudnaen kan vare fram til en ny generasjon kommer til orde. De kan så ta endelig stilling til hva de ønsker: å forlenge, forkaste, eller gjøre å avtalen permanent. ${ }^{10}$

Hvorfor en midlertidig hudna, og ikke en permanent? Det er to grunner til dette, slik Hamas ser det. For det første innebærer hudnaen at de vanskelige spørsmålene utsettes. I skissen til europeiske diplomater er verken Øst-Jerusalem eller flyktninger med som betingelser. Det at de vanskeligste stridsspørsmålene dermed er utsatt gjør hudnaen, slik Hamas ser det, mer gjennomførbar enn slutt-status modellen fra Oslo-prosessen, der forhandlingene skulle lede fram til en endelig avtale på alle de grunnleggende stridsspørsmålene samtidig.

For det andre representerer hudnaen del av en tenking om konfliktløsning forankret $\mathrm{i}$ arabisk tradisjon. Hamas skiller mellom hudna, den langvarige våpenhvilen, og tahdi'ah, kortvarige våpenhviler slik vi så flere av under den siste Gaza-krigen sommeren 2014. Formålet med den kortvarige våpenhvilen, tahdi'ah, er å få en midlertidig stopp i voldshandlinger, for å ta hånd om døde og sårede. En tahdi'ah er med andre ord ikke et skritt mot en langvarig løsning. En hudna er derimot noe mer enn en våpenhvile. En hudna representerer en implisitt form for anerkjennelse av motparten. ${ }^{11}$ Målet med en hudna, skriver Ahmed Yousef, den Hamas-representanten som har skrevet mest om Hamas' hudna-tenkning, er «å løse en internasjonal konflikt eller stammekonflikt».12 For Yousef er hudna et første skritt på vei mot en sulha, en endelig forsoningsavtale. I arabisk tradisjon representerer hudnaen en fase etter en konflikt der sinnet og følelsene skal dempes, for så at en endelig avtale om forsoning (sulha) i neste fase skal kunne

$$
\begin{aligned}
& \text { ळ } \\
& \text { Allerede i } 1988 \text { la Hamas fram en skisse } \\
& \text { om en langvarig våpenhvile med Israels } \\
& \text { davcerende statsminister Shimon Peres. }
\end{aligned}
$$

inngås. Første skritt for å avvikle en konflikt er alltid at partene enes om å unngå hevnaksjoner og mer blodsutgytelse. Ved å inngå en hudna viser partene en villighet til å inngå i en relasjon uten å true med vold eller bruke vold.

\section{Hudnaens islamske forankring}

Hudna er slik del av en tradisjonell praksis som er og har vært sentral i uformell - men standardisert - arabisk konfliktløsning. ${ }^{13}$ Samtidig er hudnaen en islamsk tradisjon, uløselig knyttet til en spesiell historisk begivenhet, hudnaen ved Hudaybiya. Denne 
referansen til å inngå en langvarig våpenhvile med fienden gir Hamas, som jeg skal komme tilbake til senere, betydelig religiøs legitimitet i diskusjoner om hudnaen med andre islamistiske grupper. På den andre siden gjør det at hudnaen kan forbindes med en konkret hendelse, som kan forstås og tolkes på ulike måter, også at forslaget om hudna kan tolkes som en taktisk manøver fra Hamas' side, snarere enn som et uttrykk for et genuint ønske om en fredsprosess.

Den historiske hendelsen det er snakk om er hudnaen i Hudaybiya i år 628 da profeten Muhammed inngikk en våpenhvileavtale med ikke-muslimene i Mekka, som muslimene var i konflikt med. Muslimene fikk gjennom avtalen rett til hvert år å dra på en tre dagers pilegrimsreise til Mekka. Etter at avtalen var inngått, kunne livet vende tilbake til det normale, karavanene fortsette å passere muslimenes tilholdssted Medina uten å bli angrepet, og handelen igjen komme i gang i handelsbyen Mekka. Våpenhvileavtalen var ment å vare i ti år. Men den ble brutt ved at noen muslimer ble drept i Mekka under muslimenes pilegrimsreise allerede det andre året . I de to årene siden hudnaen var inngått hadde tiden arbeidet for muslimene. Flere og flere hadde sluttet seg til dem, både fra Mekka og fra omkringliggende beduinstammer. $\mathrm{Da}$ Muhammed og muslimene i år 630 red inn i Mekka, etter å ha erklært at våpenhvilen var over, erobret de byen uten motstand. ${ }^{14}$

At muslimene erobret Mekka etter to år har ført til at avtalen av enkelte islamologer, som Bernard Lewis, har blitt tolket som taktikk fra Muhammeds side. ${ }^{15}$ Dette er også måten flere pro-israelske kommentatorer har forstått den islamske hudnaen. ${ }^{16}$ Det finnes for øvrig islamologer som tolker hudnaen ved Hudaybiya annerledes: Det var ikke muslimene som brøt betingelsene. Overtagelsen av Mekka var des- suten fredelig, og de fleste innbyggerne i Mekka ønsket sannsynligvis at muslimene skulle overta byen. ${ }^{17}$

For Hamas representerer det faktum at det finnes to fortolkningsrammer for deres hudnakonsept, både arabisk tradisjon og hudnaen ved Hudaybiya, en taktisk fordel. De kan tilpasse hva som vektlegges til hvem som er deres publikum. For ulike islamistiske grupper vil referansen til Hudaybiya være sentral. For et vestlig publikum vil referansen til tradisjonell arabisk konfliktløsning framheves.

En slik tvetydighet kan tolkes som uttrykk for taktikkeri. Men det er også et faktum at Hamas har referert til hudnaen i en årrekke: Allerede i 1988, året etter Hamas ble dannet, la Mahmoud Zahar, en av Hamas-grunnleggerne, fram en skisse om en langvarig våpenhvile $i$ et hemmelig møte med Israels daværende statsminister, Shimon Peres. Forslaget ble avvist av Israel, noe Hamas ga uttrykk for frustrasjon over. ${ }^{18}$ Det er også kjent at Hamas daværende leder, sheikh Ahmed Yassin i 1994, mens han var i israelsk fangenskap, presenterte en skisse for langvarig våpenhvile til sine forhørsledere. ${ }^{19}$ Videre kontaktet Hamas i Jordan i 1998 den jordanske kongen, kong Hussein, og ba ham om å overlevere et forslag til Israel om en våpenhvile med opptil tretti års varighet, basert på en enighet om opprettelse av en palestinsk stat innenfor 1967grensene. Forslaget ble ikke respondert på fra israelsk side . ${ }^{20}$ Også flere ganger på 2000-tallet har Hamas-ledere referert til hudnaen. «Vi har tilbudt Israel en våpenhvileavtale gjeldende $\mathrm{i}$ ti år som et bevis på anerkjennelse, hvis de trekker sine styrker tilbake til 1967-grensene», utalte Hamas' leder Khaled Mishal eksempelvis til den tidligere amerikanske presidenten Jimmy Carter under et møte i 2008. ${ }^{21}$ "Innenfor Hamas er det noen ideer som hele tiden er akseptert. Dette er en av de ideene», utalte 


\section{DAG TUASTAD}

Osama Hamdan fra Hamas' politbyrå om hudnaen, som var gjenstand for en gjennomgående diskusjon innad i Hamas i 20052006, både innenfor og utenfor de palestinske områdene. ${ }^{22}$

Israels respons, eller manglende respons, på hudnaen er utenfor temaet for denne artikkelen. Det som derimot er tema, er Hamas' relasjon til andre radikale palestinske islamistgrupper. Hvordan har disse blitt påvirket av Hamas og hvordan ser de på Hamas' tenkning om en langvarig hudna med Israel? Et bakteppe før dette spørsmålet diskuteres, med bakgrunn i empiri fra Libanon, er at det skal lite til for at små jihadistgrupper setter hele det palestinske leirsamfunnet i fare.

\section{Hamas og salafist-jihadist-grupper i Libanon} I Libanon i 2007 ble den palestinske flyktningleiren Nahr al-Barid totalt ødelagt og leirens 30 ooo beboere hjemløse. Bakgrunnen var at en salafist-jihadist gruppe på knapt 200 militsmedlemmer, Fatah al-Islam, med base i leiren, hadde gått til angrep den libanesiske hæren. Hæren gikk da til motangrep, noe som førte til en tre måneder lang væpnet kamp og til ødeleggelsen av leiren. Hendelsen sendte sjokkbølger gjennom det palestinske leirsamfunnet i Libanon. Særlig ett sted var usikkerheten stor, i Ain al-Hilweh, den største palestinske leiren i Libanon. Hvis dette kunne skje i Nahr al-Barid, hva da med Ain al-Hilweh, kjent for å huse flere våpen enn mennesker?23 Salafistjihadistgruppen Usbat al-Ansar (UAA) var den største militsgruppen i Ain al-Hilwe. Gruppen var blitt plassert på USAs terrorliste allerede i 2001. Den sto bak drap på moderate libanesiske religiøse ledere, den hadde angrepet nattklubber og alkoholsalg, beskutt den russiske ambassaden med granater, og drept en amerikansk misjonær. ${ }^{24}$ Hamas, som nektet å utvide sin kampsone utenfor Palestina, ble i 2000 og 2001 fremstilt som hedninger av UAA, og Hamas-medlemmer ble skutt og drept i leiren. ${ }^{25}$ I 2007, etter Nahr al-Barid-ødeleggelsen, startet imidlertid Hamas opp dialogprosjekter med både UAA og andre palestinske salafist-jihadist grupper i Libanon. Ett av formålene fra Hamas' side var å forsøke å overbevise gruppene om at rekruttering og kamp sammen med Al-Qaida ikke kunne forsvares ut fra et teologisk, islamsk perspektiv på grunn av Al-Q_aidas vilkårlige drap av muslimske sivile. Al-Oaida hadde en god del støtte i Ain alHilweh etter den amerikanske invasjonen i Irak, som følge av sterke anti-amerikanske holdninger. Både UAA og den andre store jihadist-salafist-gruppen i Ain al-Hilweh, AlHaraka al-Islamiya al-Mujahida (Den islamske kampbevegelsen, AHIM), rekrutterte og sendte angivelig krigere til Irak for å slåss for alQaida. ${ }^{26}$ Hele leiren møtte opp når krigere kom hjem i kister for å bli begravd i leiren. De mange drapene på vanlige irakiske sivile møtte imidlertid lite forståelse. Dialogene med Hamas bidro til at båndene mellom UAA og AlQaida ble svekket, og at UAA og AHIM sluttet å rekruttere jihadister til Irak. "Hamas er hodet, vi er soldatene», sa Abu Tarek al-Saadi, lederen for UAA $i$ et intervju med forfatteren. ${ }^{27}$

Hamas' primære mål var å inkludere salafist-jihadistene i palestinernes nasjonale kamp, snarere enn jihadistenes globale prosjekt. "Hvordan kan dere slåss med hverandre når Al-Aqsa-moskeen voldtas? Når vårt land grabbes av jødiske bosettere? Vi er palestinere og vår jihad må føres mot Israel», var budskapet fra Hamas-leder Ali Baraka i et intervju med den norske masterstudenten Erling Lorentzen Sogge tidligere $\mathrm{i}$ år. ${ }^{28}$

\section{Jihadistenes syn på hudnaen}

Spørsmålet om hudna var imidlertid mer sensitivt, særlig i og med at flyktningene følte 
at deres sak var blitt glemt gjennom Oslo-prosessen. Ali Baraka, Hamas-lederen i Libanon, skulle gjerne vært hele diskusjonen om hudnaen foruten, innrømmet han:29 "Når vi snakker om hudna, spør folk oss: Hvorfor? Dette er Fatah! Er Hamas Fatah?» Når Hamas likevel også kunne diskutere en langvarig våpenhvile med Israel med salafist-jihadistene var en av grunnene at hudnaen jo var godt kjent og forankret i islamsk historie. Dessuten hadde Hamas akkumulert en motstandskapital gjennom de stadige væpnede konfrontasjonene med Israel, noe som økte respekten for bevegelsen også innenfor salafist-jihadistiske grupper. Også UAA anså forhandlinger om en hudna som legitime ut fra et religiøst perspektiv. Det var akseptabelt

\section{क \\ En negativ tilnerming der målet har vert å endre Hamas gjennom boikott og isolasjon har vist seg å ikke ha noen effekt.}

for Hamas i Gaza å forhandle om en hudna, men ikke for UAA i Libanon, sa UAA-leder Tarek al-Saadi i Ain al-Hilweh - i Gaza kjente Hamas situasjonen best. ${ }^{30}$

Også Jamal Khattab, AHıмs leder, anså hudnaen som legitim ut fra et religiøst perspektiv: "Den er legitim, men på visse betingelser. En hudna kan ikke gå på bekostning av grunnleggende rettigheter. $\|^{31} \AA$ forhandle med Israel om en hudna var akseptabelt $i$ og med at Muhammed hadde forhandlet med vantro i Hudaybiya. Slik Khattab så det, var det likevel et ufravikelig prinsipp at en hudna måtte gagne muslimenes interesser for å være gyldig ut fra islamsk lov. Hvis flyktningspørsmålet ble utelatt ville ikke hudnaen tjene palestinernes interesser, og den ville dermed være ugyldig. Men samtidig refererte også Khattab til befolkningen i Gazas lidelser, og at disse hadde behov for en våpenhvile på opptil ti år: «Vi betrakter hudnaen som midlertidig, for å kunne gi palestinerne i Gaza en periode med ro."

Både АнIM og UAA har de siste par årene moderert sin politiske linje. Hensikten med Hamas' dialogprosjekt var at ideologisk moderering skulle etterfølges av moderering av politisk adferd. ${ }^{32}$ Dette har langt på vei kunne observeres i Ain al-Hilweh. AHIM og UAA arbeider ikke lenger for å rekruttere krigere for Al-Qaida, og det har ikke vært rapportert at gruppene har vært knyttet til voldelige aksjoner utenfor leiren. Tvert i mot har gruppene vært aktive i å rekruttere erklærte globale jihadist-grupper: Fatah al-Islam, ansvarlige for katastrofen i Nahr al-Barid; Jund al-Sham; alQaida og Abdallah Azzam brigadene - i en felles sikkerhetskomite for hele Ain al-Hilweh, skriver Sogge. ${ }^{33}$ Hensikten med komiteen har vært å unngå at borgerkrigen i Syria imploderer i Ain al-Hilweh, med militsgrupper stående på hver sin side i konflikten. Hamas' brannmur mot globale salafist-jihadistgrupper i leiren har så å si vokst seg større med bidrag også fra tidligere jihadister. En kultur med politisk pragmatisme på bekostning av ideologisk rigiditet har øyensynlig, i alle fall på kort sikt, vokst fram. Det er vanskelig å tenke seg at leirens sekulære grupper, Fatah eller andre PLo- grupper, skulle kunne oppnå et lignende resultat. De mangler troverdigheten, det ideologiske byggmaterialet, for å holde oss til brannmur metaforen - som skal til for å gå i seriøs dialog med gruppene.

Et trekk ved de jihadistgruppene som har blitt diskutert her er at de er basert i palestinske leirer i Libanon. De er ikke basert inne i Palestina. I tillegg til Hamas er det bare en palestinsk islamistgruppe som forfekter jihad 


\section{DAG TUASTAD}

mot Israel og som er organisert både i Libanon, Syria og i Palestina: Palestinsk Islamsk Jihad (PIJ). Dette gjør PIJ til Hamas' største islamistiske konkurrent i Palestina. I neste bolk skal vi se nærmere på pijs holdning til Hamas' ideer om en hudna med Israel.

\section{Forslaget om en hudna for Gaza}

PIj er, som Hamas, en islamistisk nasjonalistbevegelse snarere enn en global jihadistbevegelse. Det at Hamas trakk seg ut av Syria, og dermed mistet Iran som sponsor, har PIJ - som ikke har forlatt Damaskus - kunne kapitalisere på. De har beholdt pengestrømmen, samtidig som de ikke har blitt utsatt for byrden med å styre Gaza slik Hamas har. Et PIJ uten ansvar for konsekvensene av å angripe Israel med raketter har også kunnet kritisere Hamas for manglende motstandsvilje. Før den siste Gazakrigen kunne det observeres at PI ikke overraskende økte sin popularitet i Gaza på bekostning av Hamas. ${ }^{34}$

I 2010, i et intervju med artikkelforfatteren, fortalte Anwar Abu-Taha fra PIjs ledelse basert i Syria, at PIj var motstandere av Hamas' skisse til en langvarig hudna med Israel. En slik hudna ville innebære en anerkjennelse av Israel, noe gruppen var mot. ${ }^{35}$ En hudna ville videre kreve direkte forhandlinger med Israel, noe gruppen også var mot. Slik Abu-Taha så det, var hele Hamas' fortolkning av hudnaen ved Hudaybiya basert på feilaktige slutninger: «Da Muhammed inngikk hudnaen var han den sterke parten, så han kunne få fordelaktige betingelser. I politikk er det alltid den svake parten som blir offer for den sterkestes betingelser, og palestinerne var nå den svake parten.» Muslimer skulle ikke inngå en hudna med ikke-muslimer når de var den svake part, ifølge Abu-Taha. Hvis det kom til en folkeavstemning om en hudna, ville pIj likevel bøye seg for utfallet. Dette var et essensielt punkt, fordi det betydde at om pijs motstand mot en hudna var både taktisk og ideologisk basert, var den ikke absolutt.

I juni 2013 ble PIjs talsmann Khader Habib intervjuet av artikkelforfatteren i Gaza. Han bekreftet da at PIj var motstandere av en langvarig hudna med Israel. Det var følgelig oppsiktsvekkende da det kom rapporter under Gaza-krigen 2014, om et felles tilbud fra Hamas og pij om en langvarig hudna mellom Israel og Gaza..$^{36}$ PIj hadde øyensynlig akseptert Hamas' linje når det gjaldt hudnaen. Det er derfor av interesse å se nærmere på skissen fra Hamas og PIJ, som nedenfor presenteres i sin helhet. I den grad betingelsene kan ses som pragmatiske og gjennomførbare heller enn mer programmessige vil dette tyde på at Hamas har økt sin ideologiske og politiske innflytelse på PIJ .

Hamas' og pijs betingelser for en langvarig hudna mellom Gaza og Israel:

1. Cjensidig slutt på krigshandlinger og tilbaketrekking av stridsvogner til tidligere posisjoner, med påfølgende mulighet for jordbrukere til å igjen kunne arbeide på jorda i grenseområdet mellom Gaza og Israel.

2. Frigivelse av alle de palestinske fangene fengslet etter 23. juni 2014 [da tre israelske bosettere ble kidnappet på Vestbredden], og forbedring av forholdene for palestinske fanger, særlig fangene fra Jerusalem, Gaza og 1948-området [Israel].

3. Oppheving av blokaden av Gaza med åpning av grensene for varer og personell, tillatelse til å innføre alle matvarer, forsyninger for industriproduksjon, samt konstruksjon av et elektrisitetsverk med stor nok kapasitet til å dekke hele Gaza.

4. Bygging av en internasjonal havn og en internasjonal flyplass, under overvåking av FN og ikke-forutinntatte land.

5. Utvidelse av fiskerisonen til ti kilometer 
med mulighet for fiskere til å bruke større fartøy.

6. Omgjørelse av grenseposten i Rafah til en internasjonal grensepost, under overvåking av FN og arabiske og vennligsinnede land.

7. Signering av en våpenhvileavtale av ti års varighet, med utplassering av internasjonale observatører ved grensene.

8. Forpliktelse fra okkupasjonsmakten til å ikke krenke palestinsk luftrom, og lettelser på restriksjonene for troende til å be ved Al-Aqsamoskeen [i Jerusalem].

9. Okkupantmakten skal holde seg unna den palestinske regjeringens interne arbeid, og ikke hindre nasjonal forsoning.

\section{a \\ A forhandle med Israel om en hudna var akseptabelt $i$ og med at Muhammed hadde forhandlet med vantro i Hudaybiya.}

10. Gjenoppbygging, beskyttelse og utvikling av industrisonen i grenseområdene.

Disse betingelsene kan vanskelig tolkes som annet enn uttrykk for en pragmatisk holdning snarere enn den ideologisk og religiøse absolutisme som har kjennetegnet globale jihadistgrupper. Betingelsene framstår nærmest som minimumskrav snarere enn maksimumskrav. De er dessuten i all hovedsak forankret $i$ allerede inngåtte avtaler. ${ }^{37}$

På den andre siden kan framleggelsen av skissen sies å ha en bismak av taktikk. Hadde det vært et seriøst diplomatisk initiativ fra Hamas og PIj ville de ventelig lansert det gjennom andre kanaler enn å lekke det til pressen i korridorene i Kairo etter først å ha sagt nei til en kortvarig våpenhvile, slik tilfellet var nå. $3^{8}$ Dessuten mangler forutsetningene internt $i$ palestinsk politikk for å diskutere forslaget:
Skulle Israel godta betingelsene, eller å forhandle om dem, ville det innebære en tilsidesettelse av PLo, og også nærmest være et grønt lys for en palestinsk stat i Gaza. Sannsynligheten er lav, for å si det mildt, for at reelle forhandlinger om en slik hudna vil kunne finne sted før en genuin palestinsk forsoning er på plass med én forent ledelse.

Like fullt, selv om forslaget om en hudna under Gaza-krigen kan oppfattes som taktisk motivert ut fra situasjonen Hamas og PIj befant seg $\mathrm{i}$ under krigen, betyr ikke det at Hamas og PIJ ikke står inne for forslaget. Forslaget viser med all tydelighet at Hamas har et diplomatisk alternativ til den væpnede kampen, og at de har lykkes med å få tilslutning for dette alternativet fra sin største konkurrent innenfor den islamistiske politiske arenaen. Når PIJ har endret posisjon når det gjelder hudnaen så kan nok dette riktignok også ha å gjøre med vekstproblemer innad i PIJ.

Det har blitt rapportert fra Gaza om intern uro i pIj og at medlemmer har fremmet krav om en mer strømlinjeformet organisasjon og mer interndemokati. PIjs økte popularitet på Gaza-stripen gjør at bevegelsen i større grad må konsentrere seg om ulike politiske spørsmål, og ikke bare egen evne til å gjennomføre væpnede operasjoner mot Israel. ${ }^{39}$ Sånn sett, når det gjelder det som er den primære diskusjonen her; om Hamas' ideologiske påvirkning på jihadistgrupper også gjelder i deres forhold til pij, er det kanskje ikke utelukkende påvirkning fra Hamas som kan forklare at PIJ har skiftet posisjon. Men om ikke ideologisk påvirkning fra Hamas er en tilstrekkelig betingelse er det uansett en nødvendig betingelse for å forklare endringen. PIj har skiftet posisjon og blitt enige med Hamas på et område hvor de tidligere har kritisert Hamas, og som de knapt ville tatt stilling til foruten påvirkning fra Hamas. Dette viser at brannmur-modellen er 
relevant også når det gjelder Hamas' nåværende rolle i Gaza.

\section{Konklusjon}

Formålet med denne artikkelen har for det første vært å belyse et lite kjent område ved Hamas' politikk: deres alternative forslag til fredsprosess. Hamas' forslag til hudna er på langt nær viet samme oppmerksomhet i vestlige media, faglige artikler og politiske miljøer, som deres bruk av politisk vold. Når det gjelder politisk tilnærming til Hamas er dette et paradoks. En negativ, sanksjonerende tilnærming der målet har vært å endre Hamas gjennom boikott og isolasjon har vist seg å ikke ha noen effekt. En positiv tilnærming, der Hamas' eget program ble tatt på ordet, ville slik sett kostet lite. I verste fall ville situasjonen forblitt uendret, i beste fall kunne en alternativ fredsprosess blitt resultatet. Det faktum at ledere fra Hamas har referert til en langvarig hudna siden bevegelsen ble dannet, samt at hudnaen er forankret innad i Hamas' organer etter inngående diskusjoner, gjør tiden overmoden til å utforske hudna-tenkningen nærmere også på politisk nivå.

Det andre målet med artikkelen har vært å analysere Hamas i lys av modellen om at moderate islamistiske grupper kan tjene som en brannmur mot mer radikale jihadistiske grupper.40 Både når det gjelder salafistjihadist-grupper i Libanon og PIJ i Gaza har Hamas fungert modererende. I Libanon har flere jihadistgrupper inntatt en mer pragmatisk og forsonende holdning etter å ha vært involvert i dialogprosjekter med Hamas. Andre faktorer enn ideologisk påvirkning fra Hamas kan også ha bidratt til denne utviklingen, men Hamas' rolle fremstår like fullt som sentral. Det samme kan sies om forholdet til PIj i Gaza. PIj har når det gjelder en langvarig hudna med Israel endret posisjon, og støtter nå
Hamas' forslag om en langvarig våpenhvile. Dette bidrar til å styrke hudnaen som et potensielt diplomatisk alternativ til den skakkjørte Oslo-prosessen.

Hamas kan virke modererende på mer radikale jihadistgrupper og påvirke PIJ politisk og ideologisk fordi de snakker samme språk så å si; de har større ideologisk nærhet og felles religiøse referanser for sine diskusjoner. Hamas' islamistiske posisjonering gir bevegelsen en troverdighet som de sekulære palestinske gruppene mangler.

Samtidig er Hamas' skisse til hudna ett av midlene Hamas kan bruke for å nå sine mål. Det kan være et alternativ til politisk vold så lenge betingelsene innfris. Inntil da forblir imidlertid væpnet kamp et kjennemerke for Hamas, som skiller bevegelsen fra PLO. Hamas' involvering i væpnet kamp mot Israel øker deres troverdighet blant mer radikale palestinske grupper. Paradokset er at jo mer involvert Hamas er i væpnet kamp mot Israel, jo større gehør får de øyensynlig blant radikale grupper for sitt forslag om hudna.

$$
\cdot f \cdot
$$

1 Lynch, Marc: "Islam divided between Salafi-jihad and the Ikhwan", i Studies in Conflict \& Terrorism, vol. 33, nr. 6, 2010 , s. 467.

2 Sara Pantuliano, Kate Mackintosk og Samir Elhawary: "Counter-terrorism and humanitarian action", i HPC Policy Brief 43, October 2011.

3 Reuven Paz: "Jihadists and Nationalist Islamists: Al-Oa'ida and Hamas", i Assaf Moghadam og Brian Fishman (red.), Fault Lines in Clobal Jihad: Organizational, Strategic, and Ideological Fissures. London: Routledge, 2011, s. 208.

4 Paz 2006, ss. 210-211. Al-Qaida tilslutter seg Al Wala' Wal Bara' doktrinen: for alt som er islam, mot alt som ikke er islam, Lynch, Marc: "Islam divided between jihad and the Muslim Brotherhood," i Assaf Moghadam og Brian Fishman (red.), Fault Lines in Global Jihad: Organizational, Strategic, and Ideological Fissures. London: Routledge, 2011, s. 167.

5 Gunning, Jeroen: "Peace with Hamas? The transforming potential of political participation," i International Affairs, vol. 80 , nr.2, s. 250

6 "The nail in the wood: an interview with Ismail Abu Shanab," i Open Democracy, 4. september 2003. 
https://www.opendemocracy.net/people-debate_97/ article_1469.jsp

7 Milton-Edwards, Beverley \& Stephen Farrell, Hamas. Cambridge: Polity Press, 2010, s. 278; Paz, s. 209.

8 Tamimi, Azzam: Hamas. Unwritten Chapters. London: Hurst \& Company, 2007, s. 251.

9 Atran, Scott: "Hamas May Cive Peace a Change, " i New York Times, 18. desember 2004. http://query.nytimes. $\mathrm{com} / \mathrm{gst} /$ fullpage. $\mathrm{html}$ ?res=9AoDE5D91530F93BA25751 C1A9629C8B63 (9 June 2010)

10 Intervju med forfatteren, Damaskus, mars 2010.

11 Begner, Michael, The hudna concept: Harbinger of peace or prolonger of conflict? The Henry Jackson Society: Project for Democratic Geopolitics, 2009, s.5.

12 Yousef, Ahmed, Hudna (Truce). Gaza: House of Wisdom, 2006.

13 Gellmann and Vuinovich: "From Sulha to Salaam: Connecting Local Knowledge with International Negotiations for Lasting Peace in Palestine/Israel," i Conflict Resolution Quarterly, vol. 26, nr. 2, 2008.

14 Vikør, Knut, Ei verd bygd på islam. Oversikt over Midtaustens historie. Oslo: Samlaget, 1993, s. 63.

15 Lewis, Bernard, The Arabs in History. New York: Oxford University Press, 1950, s. 45.

16 Sharon, Moshe: "Hudnah and sulh do not mean "peace"," i Think-Israel. November-December 2007. http://www. acpr.org.il/nativ_e/o85-nativ-toc.htm Pipes, Daniel. 1999:"Al-Hudaybiya and Lessons from the Prophet Muhammad's Diplomacy," i Middle East Quarterly, September 1999 .

17 Watt, WM. Muhammad: Prophet and statesman. New York: Oxford University Press, 1961, s. 202.

18 Milton-Edwards, Beverley, og Alastair Crooke: "Waving, not drowning: Strategic dimensions of ceasefires and Islamic movements" i Security Dialogue, vol. 35, nr. 3, 2004, S. 299.

19 Tamimi, s 102.

20 Halevi, Jonathan Dahoah: "The Hamas interest in the Tahdiya (Temporary Truce) with Israel," i Jerusalem Center for Public Affairs, vol. 8. nr 4, 2008, s. 43-4.

21 "Meshal offers 10-year truce for Palestinian state on '67 borders," i Haaretz. 21. april 2008 http://www. haaretz. $\mathrm{com} /$ news/meshal-offers-10-year-truce-for-palestinianstate-on-67-borders-1.244339

22 Intervju med forfatteren, Damaskus, mars 2010.

23 Sogge, Erling Lorentzen: "The local politics of Clobal Jihad". MA thesis, University of Oslo, september 2008, s. 23.

24 Den australske ambassaden, www.law.gov.au/ag

25 Gambill, Gary C. 2003, "Ain al-Hilweh: Lebanon's 'Zone of Unlaw”, i Middle East Intelligence Bulletin, vol. 5, nr. 6.

26 Gambill 2003.

27 Intervju med forfatteren, flyktningleiren Ain al-Hilwe, april 2010.

28 Sogge, 40.
29 Intervju med forfatteren, Beirut, april 2010.

30 Intervju med forfatteren, flyktningleiren Ain al-Hilweh, april 2010.

31 Intervju med forfatteren, flyktningleiren Ain al-Hilweh, april 2010.

32 Moderasjon er her forstått som å være åpen for at andre perspektiver enn ens egne også kan være valide, noe som impliserer en villighet til å kunne inngå kompromisser. Begrepet forstås ikke som synonymt med tilslutning til liberale verdier, eller at man ikke ønsker større forandringer av status quo, se Schwedler, Judith: "Can Islamists Become Moderates?: Rethinking the Inclusion-Moderation Hypothesis", i World Politics, vol. 63, nr. 2, 2011, ss. 351-2.

33 Sogge, ii.

34 "Islamic Jihad gains support in Gaza as Hamas declines" i Al Monitor, 10. april 2014, http://www.al-monitor. com/pulse/ru/originals/2014/o4/islamic-jihad-supportgaza-expense-hamas.html

35 Intervju med forfatteren, Damaskus, mars 2010.

36 “ قئدهتل قرشعلا داهجلاو سامح طوش " betingelser for en våpenhvile), Maan News, 16. juli 2014, http://www. maannews.net/arb/ViewDetails.aspx? ID $=713512$

37 Den såkalte "Agreement on movement and access", mellom palestinske selvstyremyndigheter og Israel i 2005, stipulerer at en internasjonal havn i Gaza skulle bli bygd, at internasjonale observatører skulle overvåke grenseoverganger mot Gaza, og at varer og personell skulle kunne flyttes uhindret gjennom overgangene http://www.state. gov/s/1/2005/87237.htm En ti km lang fiskerisone er faktisk mindre enn det Oslo-avtalen stipulerte, og var også del av våpenhvileavtalen etter minikrigen mellom Israel og Hamas i 2012. Når det gjelder fengslingen av fanger etter 23. juni var en stor andel av de fengslede fangene sluppet fri som del av fangeutvekslingsavtalen Shalit mellom Hamas og Israel, og er dermed et brudd på denne avtalen.

38 Maan News 2014.

39 "Islamic Jihad members push for internal reform," i Al Monitor 15. april, 2014. http://www.almonitor.com/pulse/originals/2014/o4/islamic-jihadinternal-reform-elections-palestine.html

40 Moderat - radikal referer her til gruppens tenkning om bruk av politisk vold, se Schwedler 2011, s. 356-357. 